\title{
Derrida's Concept of Hos(ti)pitality and Hate Crime in Turkey
}

\author{
Güneş Koç \\ Istanbul Arel University
}

This article considers hate crime against Syrian migrants in Turkey within the context of the Turkish government's politics of hospitality, with reference to Derrida's notion of the hos(ti)pitality. It analyzes hate crime directed at Syrian refugees as reported in Turkish newspapers between 2014 and 2021. The data analysis used Van Dijk's Critical Discourse Analysis (CDA) method. The findings reveal that hate crimes resulted from hate speech collectively targeting Syrians as a burden and threat for the nation. The government's hospitality grants Syrian migrants a status of guest and the guest becomes the hated other or enemy which leads to hate crime.

Keywords: Syrian migrants, threshold, hos(ti)pitality, Turkish state's politics of hospitality, hate crime, Derrida's concept of hos(ti)pitality, hate crime in Turkey

\section{INTRODUCTION}

This paper considers Turkey's official policies for hosting Syrians and the hate crimes against Syrian refugees with Derrida's concept of hos(ti)pitality and threshold (2000a). The threshold is a place of encounter with a stranger that comes as a guest. The stranger is both a potential threat and a potential friend and the encounter balances between hospitality and hostility. In the twenty-first century, the refugee question involves negotiating borders, creating and managing thresholds, and understanding an ambivalent state of hos(ti)pitality in the host country.

Refugees account for a large proportion of Turkey's increase in population. Turkey's "open door" policy welcomed Syrian refugees since the Syrian war began (Koca, 2016, p. 56). Since April 2011, Turkey has experienced a significant increase in immigration. Toprak's data (2019) indicates that 4 million people live in Turkey under temporary or international protection status and 92\% (3.6 million people) are Syrians (UNHCR Türkiye İstatistikleri). Recep Tayyip Erdogan called Syrian refugees "our brothers," which underlined the common Islamic religion between many Turks and Syrians (Karaveli, 2013) and emphasized welcoming Syrians as guests who need God's help and Turkey providing that help. "For our Syrian brothers who ask when God's help will come, I want to say: God's help is near." (Recep Tayyip Erdoğan (05.05.2013). Twitter Web Client). The humanitarian stance has been furthermore prolonged to seek support with an "open door" policy including narratives of "historical and geographical necessities," "religious fraternity," and "ethnic kinship" (reference to Erdoğan (November 2014), in Koca, 2016, p. 56). The Turkish government's conditional hospitality operated at two levels of state policy. On the one hand, the refugees were instrumentalized as fearsome others and the possibility of them pouring into Europe was used as a bargaining chip in negotiations with other countries. On the other hand, the brotherhood/sisterhood discourse was not backed by a consistent legal framework and integration policy. The Turkish state did not 
provide hundreds of thousands of Syrian children any education. Refugees faced many problems when trying to access the healthcare services and accommodation (Şirin-Öner \& Genç, 2015, p. 12; Erdoğan, 2017). Balkıliç and Teke Lloyd (2010) note the significance of the use of the religious term ümmet, meaning a community bound in one faith, in the discourse used by the state as it welcomed the Syrian refugees (p. 560). The use of such discourse rather than more universal rights-based language, they claim indicates a new geopolitical narrative that has arisen around AKP's (Adalet ve Kalkınma Partisi/Justice and Development Party) efforts to wage Islamic politics (Balkılıç \& Teke Lloyd, 2010, p. 560).

AKP's international politics in the 2010s focused on elevating Islamic and denigrating Western values, especially with reference to European border policies concerning Syrian refugees. The AKP party criticized the EU's reticent response to the refugee crisis and the focus on state security in Europe. AKP tried to present Islamic norms as a more viable mechanism for providing solutions to such global problems. These norms informed policies conceiving the Syrian refugees in Turkey as "temporary" guests. This ended up making them particularly vulnerable. Under the temporary protection regime, the refugees' identities as guests were linked to the Islamic notion of ümmet, with no reference to cosmopolitan human rights (Balkıliç $\&$ Teke Lloyd, 2010, p. 560). Temporary protection status does not provide institutionalized legal rights to refugees, but only temporary residence covered by the generosity of Turkish civil society (Ozturk \& Guler, 2020 , p.2). Without a rights-based discourse, Syrian refugees and migrants are vulnerable to sudden expulsion at any moment and held at the whim of AKP's wishful politics (Balkılıç \& Teke Lloyd, 2010, p. 560). Turkey as a benevolent host helping a Muslim community had the conditionality of the political discourses that Syrian refugees should stay as "short-term guests". The perception of refugees as guests increases the expectation that the sooner they return to their home the better (Ozturk \& Guler, 2020, p. 7). Turkey did not respond to the high inflow of refugees with a strong integration policy.

This created conditions for the ambivalence inherent to hos(ti)pitality to play out fully, with an eventual surge in xenophobia within Turkish society. The current migration law confers only temporary protection to the refugees and makes it clear that they are supposed to stay only for a limited time. This conceptualization serves to limit the country's hospitality. Ironically, it also sets up a frame in which the refugees are certain to overstay their welcome, at which point the other side of hos(ti)pitality comes to the forefront. When the Syrian war began and an increasing number of refugees started arriving in Turkey, hate crime and hate speech against migrants in general, but especially against Syrians, increased. This phenomenon is especially pronounced in the cities and districts with many Syrian refugees. From 2015 to 2020, the inflow of refugees has accelerated, putting further strain on hospitality, and bringing about a further surge of racism. Suddenly, Syrian migrants under temporary protection increased from 0 in 2011 to 3,653,619 in 2021. Between 2013 and 2014, the numbers of migrants jumped from 224,655 to 1,519,286 and from 2014 to 2017 the numbers increased to 3,426,786. (T.C. İçişleri Bakanlığ1 Göç İdaresi Genel Müdürlülüğü (17.03.2021))

Frustration increased because of the expectation that the refugees would and should go back. The refugees' temporary status under Turkish law turned the country into a threshold within which they lead a precarious existence exposed to the vagaries of a fragile hospitality that always bears the potential for hostility. When the seeds of hostility invariably take root, the refugees face xenophobia, hate speech, and hate crime that lead to hate murder. These acts are not sporadic but have turned into an ongoing conflict.

\section{THEORETICAL FRAMEWORK}

\section{Hospitality and Hos(ti)pitality}

Hos(ti)pitality, understood as an act of social solidarity and humanity, has been documented since late antiquity and appears in early works such as the Bible and the Homeric epics. A significant conceptual shift that informs contemporary Western thinking on the topic came in the Age of Enlightenment with Kant (1970), who in his Perpetual Peace spoke of laws of hospitality. Kant's (1970) universal hospitality, "the right of the stranger not to be treated with hostility when he arrives on someone else's territory" (p. 105), is based on the notion of cosmopolitan rights. Makris (2006) argues that Kant's vision amounts to a conditional hospitality delimited by the logic of state sovereignty, security, and survival. Kant's 
cosmopolitanism justifies a conditional hospitality that avoids the hazards of extending it unconditionally (Makris, 2006). Because of the deontological nature of Kant's discourse, the relationship with the foreigner is regulated juridically (Kordvani, 2006, p. 14).

The word "hospitality" comes from the root of the Latin word for "guest": *hosti-pet-, i.e. hospes, with the second component (*pot-) signifying master (Benveniste, 1973, pp. 71-83). In coining the neologism hos(ti)pitality, Derrida (2000a) underlines the "double bind" and "the troubling analogy in their common origin between hostis as host and hostis as enemy, between hospitality and hostility" (pp. 14-15). In Derrida's terms, hospitality includes linguistically, etymologically, and metaphysically the element of an ontological threat and is therefore conceived as hos(ti)pitality (Makris, 2006, p. 4). Derrida (2000a). This highlights two characteristics of Kant's notion of hospitality: its basis in rights rather than philanthropy and its reliance on the idea of world citizenship (p. 3). The various etymological dimensions of the word hosthouseholder, stranger, and enemy-allow us to reflect on power relations as they manifest themselves in our encounters with guests such as strangers and homeless people (Derrida, 2001, p. 19). Without a right, the new arrival is a parasite, "a guest who is wrong, illegitimate, clandestine, liable to expulsion or arrest" (Bati $\&$ de Vries, 2000, p. 60). The power of hospitality is power over - sovereign power and possession of the home and its space (Derrida, 2000b, p. 41). It is the power to control thresholds, to decide whether to welcome or reject (Bati \& de Vries, 2000, p. 60).

In Derrida's understanding, unconditional hospitality differs from conditional hospitality in that it does not refer to a calculative frame defined through knowledge regimes, scientific or otherwise; it depends on a "decision without measure" structured around undecidability itself and commits to it (Fotou, 2016, p. 204). Unconditional or pure hospitality entails welcoming the newcomer before any identification, "whether or not the new arrival is a citizen of another country, a human, animal, or divine creature, a living or dead thing, male or female" (Bati \& de Vries, 2000, p. 77).

\section{The Threshold}

Sovereignty over the house limits hospitality (here the house can also serve as a metaphor for the nation or the state): "There is no hospitable house. There is no house without doors and windows. But as soon as there are a door and windows, it means that someone has the key to them and consequently controls the conditions of hospitality. There must be a threshold. But if there is a threshold, there is no longer hospitality" (Derrida, 2000a, p. 14). In a home that has a door, a threshold of inclusion and exclusion, hospitality can only be conditional. The conditional nature of hospitality becomes manifest in the process of inclusion that the guest must go through as they cross the threshold. The door is a boundary between the inside and the outside and represents the threshold as "a transgressive step" (Bati \& de Vries, 2000, p. 75). Derrida (2000b) focuses on the door and the window in their function of opening the home and its borders to the outside. This function, he claims, is a precondition for sovereignty and mastery over one's home (Derrida, 2000b). The border at the threshold is passed with the permission of the host. The first step towards hospitality is asking the stranger's name: they are identified like in a court of law (Naas, 2006, p. 244). The arrival can be an immigrant, an emigrant, a guest, or a simply a newly come stranger. It is in this way that uninvited refugees and strangers arrive at the border of a nation state, ask for help, and negotiate hospitality with their prospective hosts (Makris, 2006, p. 3).

Derrida's hos(ti)pitality aporia balances between seeing migrants and refugees as a threat (Stocker, 2006) and opening a place for the other (Çoban, 2015, p. 156). Having arrived at the border as strangers, the newcomers become allies or adversaries as soon as they cross over. Strangers are guests as long as they are allies and stay for a limited time. The threshold's temporality is thus organized around the temporary nature of the guest's stay. Its extension, for the guest, is the country in its entirety. Even if the country's borders are open, it is a space within the threshold for the guest as long as they are expected to stay for a limited time. Defined in terms of sovereignty, hos(ti)pitality is an aporia - an undecidable state of exception between hospitality and hostility (Derrida, 1998, pp. 71-73). Like Levinasian perception, it manifests in an ambivalent space of encounter full of promise and terror (Derrida, 1998, pp. 71-73). By emphasizing the seed of hostility inherent to hospitality, the concept of hos(ti)pitality offers a good framework for understanding why the state often treats guests or refugees as enemies. The deconstruction of hos(ti)pitality 
uncovers the uneasy relationship between hospitality and hostility at the heart of the humanitarian act of welcoming strangers, refugees, and homeless people into one's home: it reveals the potential for rejection, suspicion and violence that it entails (Makris, 2006, p. 12).

As the foreigner identifies with their name and story and makes their claim for welcome or asylum, they are exposed to the studying gaze of the host that questions their motives and honesty. If the host is dissatisfied with the results of the inquiry it withdraws its welcome, but also punishes the foreigner for dishonesty (Kordvani, 2006, p. 24). Within the threshold the distinction is that between the guest and the "parasite," the latter defined as an illegitimate, clandestine arrival liable to expulsion or arrest (Derrida, 2000b, p. 59, 61). The Syrian refugees in Turkey have a status created by the Temporary Protection Regulation. The regulation is designed to accommodate refugees and stateless people, but it is a prime example of a conditional formulation of hospitality that fosters from the very start all of the ambiguities inherent to hos(ti)pitality. Konukseverlik, the Turkish concept for hospitality and an important element of national identity, cropped up frequently in public and state discourse as the Syrian refugees started arriving. The Syrian migrants were often referred to as "our brothers and sisters" (using the genderless kardeş, meaning, roughly speaking, "sibling") (Atalay, 2014). However, the temporary nature of konukseverlik, grew more and more manifest as the Derrida's Concept of Hos(ti)pitality and Hate Crime in Turkey arrivals overstayed their welcome and hospitality tipped over into hostility. One consequence was the surge of hate violence and hate speech. With the increasing number of refugees and migrants within the threshold, Turkey became the space of a double negotiation. Internally, in the absence of a comprehensive integration policy, the newcomers' status, tenuously defined under the Temporary Protection Regulation, became a subject of intense dispute. Externally, perceived as fearsome others in Europe, the Syrian refugees became an instrument in Turkey's bargaining with other nations. Turkey's shift from an open-door policy to a temporary guest policy posed significant challenges for the Syrian refugees in terms of how they constructed and sustained their identity. The guest status raised the question of whether the migrants would go back to Syria at the end of the war, or, indeed, at all and brought into stark relief the lack of a migration law.

\section{Definitions of Hate Speech and Hate Crime \\ Hate Speech}

The Term "Hate Speech" According to the Council of Europe's Committee of Ministers. Recommendation 97(20) "shall be understood as covering all forms of expression which spread, incite, promote or justify racial hatred, xenophobia, anti-Semitism or other forms of hatred based on intolerance, including: intolerance expressed by aggressive nationalism and ethnocentrism, discrimination and hostility against minorities, migrants and people of immigrant origin" (Council of Europe Committee of Ministers. Recommendation No. R (97) 20, 30 October 1997). Hate speech constructs the "us" and the "other" and when spread by media deepens the cleavage between "us" and "other" (Kush, 2006, p. 99). Parekh (2006) describes hate speech as expressing hostility against a group of people who have a special kind of feature and in which the hate against that group is explained, supported, or provoked. Hate includes pejorative feelings such as rejection, wish to harm, to eliminate, to disclose the target group, to silence it, or to repress it (p. 214). Binark \& Çomu (2012) collected hate speech within six categories such as "political hate speech, hate speech against women, hate speech against foreigners and immigrants, sexual-identity based hate speech, religious belief and sect based hate speech, hate speech against disabled people and diverse diseases." Hate speech against foreigners and immigrants is described as: "May target foreigners, immigrants and/or ethnic groups. Generally caused by economic reasons, it is frequently observed in Turkey and in the world. Besides, this type of hate speech is also fed by racism. It positions different ethnic groups as the source of fear and concern and marks them as "enemies"' (Binark \& Çomu, 2012).

\section{Hate Crime}

Hate speech is the origin of the process which leads to hate crime, because it points the way to the intolerance and hatred that results in hate crime (İnceoğlu \& Sözeri, 2012, p. 2). In 1986, hate crime was first associated with hate speech. Hate speech is used since 1990 in a broader context and includes hate 
crime against race, religion, political beliefs, sexual orientation, nationality, and gender roles (Yazıc1, 2016, p. 119). Hate crime is defined as an offense against the victim because of the actual or perceived race, color, religion, disability, sexual orientation, or national origin of that victim (Sullaway 2004, p. 250). Hate crime is also defined as a crime in which "the defendant intentionally selects a victim because of the actual or perceived race, color, religion, national origin, ethnicity, gender, disability, or sexual orientation of any person" (Violent Crime Control and Law Enforcement Act of 1994, Public Law 103-322, H.R. 3355) (Sun, 2006, p. 597). The conceptualization of hate crime on the basis of the legal definition is "a manifestation of intergroup conflict or violence' (e.g., Levin \& McDevitt, 2002; Levin \& Rabrenovic, 2001) motivated by the uniqueness of the victim(s), "because the offender only targets victims with different group memberships' (Sun, 2006, p. 598). The social exclusion, economic burdens, bad working conditions, and discrimination practices turn migrants into scapegoats and targets of the hate speech and hate crime.

\section{Hate Crime in Turkey}

According to the 2019 report of IHD (the acronym for the Turkish organization named Insan Hakları Derneği translated into English as Human Rights Association), in 2019, one person has been murdered by a racist attack, five people murdered in a gender-based attack against LGBTI people, and twenty-seven people injured from a racist attack (İnsan Hakları Derneği, 2020, p. 3). The number of real incidents of hate crime is probably more than the report of the Human Rights Association. For example, the "Report on hate crime based upon homophobia and transphobia" published in May 2020, notes that hate crimes based upon homophobia and transphobia are higher than official reports (İnsan Hakları Derneği, 2020, p. 3). This report says 150 hate crime cases happened in 2019. Most of these crimes are committed in schools, in public transport, in the streets, or within the other public spaces. The Hirant Dink Association's 2018 report on media (Asulis, 2018) analyzed all national and 500 local newspapers and identified 18 cases of hate speech produced by the media. The report says that hate speech most often targets those of Jewish, Armenian, and Syrian background. The Hirant Dink Association's "Hate speech and discriminatory discourse in media 2019 report" notes that in 2019 the Turkish printed media has a daily average of 17 news and columns with hate speech. The media has intensified prejudices against 80 different ethnics, religious, and national identities (Asulis, 2019, p.15). The Uğur Mumcu investigator association's "report about the discriminative discourses displayed during the 2019 local elections within the media" (Uğur Mumcu Araştırmac1 Gazetecilik Vakfi, 2018) states that the wide-ranging discriminative discourse includes sexism, xenophobia against the refugees, and ethnic discrimination (İnsan Hakları Derneği, 2020, p. 3).

The Hrant Dink Association's research considers the last five years of daily discrimination expressed through hate speech against refugees. It reports that hate crime increased in the recent years against Syrian refugees and Kurdish seasonal workers. In 2020, the Human Rights Association registered fourteen racist attacks and seven murders (including three Syrian children). Since 2010, there have been 280 cases of racist attacks, 15 murders, and 1097 injured people (İnsan Hakları Derneği, 2020, p. 5). Their research indicates an increasing number of hate crimes focused on Syrian refugees who are under temporary legal protection. At least the registered news about hate speech and hate crime against Syrian refugees there are news starting from 2014 to state.

\section{Hate Speech in Social and Mass Media in Turkey}

The existing research as well as reports and press releases from international NGOs (Özden, 2013) indicate a significant level of prejudice against Syrian refugees. Instead of the government's proclaimed guest-hospitality concept of welcoming the refugees, refugees are seen mainly as burden (Kirişçi, 2014) and "anti-refugee discourse is especially prevalent in those areas that have recently become home to large refugee populations" (Lazarev \& Sharma, 2017, p. 206). According to the reports, tensions have developed between local residents and Syrian refugees because of "economic hardships, social problems and changing ethnic and sectarian balances" (Orsam, 2015, as cited in Genç \& Özdemirkıran-Embel, 2019, p. 170). Main critical points about the hos(ti)pitality against refugees are "costs to the national budget, increased local rents, disruption to the labor market, and depressed wages" (Kirişci, 2014). The prejudices include cultural differences between the Turkish population and Syrian refugees, such as "not having manners, speaking 
and laughing very loudly, being uneducated, having too many children, and harassing women on the streets" (Özden, 2013). Hos(ti)pitality against Syrians also results from local residents blaming Syrian refugees for the attack in Reyhanli, when the Turkish army intervened in the Syrian war (Lazarev \& Sharma 2017, p. 206). A national poll in November 2013 revealed that "86 percent of Turks do not want to allow more Syrian refugees in the country and that 30 percent of respondents also wanted the refugees to be deported to Syria" (Balci, 2014, cited in Lazarev \& Sharma, 2017, p. 207). The study of Lazarev \& Sharma (2017) shows significant prejudice against Syrian refugees: 51 percent of the respondents think that despite the ongoing war, Turkey should not host Syrians; 57 percent said government spending on refugees is excessive and should be cut; 61 percent distrusted the refugees; 53 percent do not want to donate anything to the refugees; and 39 percent do not want a Syrian refugee to work in their neighborhood (p. 209). The study revealed that Islam can play a role in attitudes, the Sunni and Muslim identity of the Syrian refugees reduced prejudices (Lazarev \& Sharma, 2017, p. 217). In a study between October 2014 and August 2015 that interviewed 358 muhtars of 786 urban neighborhoods in Istanbul, the muhtars mostly identified security issues related to Syrian migration such as beggars, aggressive behaviors, housing problems, hygienic conditions, and the problems of migration management (Genç \& Özdemirkıran-Embel, 2019, pp. 168-194). The muhtars see the Syrians as a source of trouble because of Istanbul's lack of a common framework on legal integration results in refugees depending on the hospitality of local officials (Genç \& ÖzdemirkıranEmbel, 2019, pp. 168-194).

The research on hate speech revealed that in comparison to the traditional media, the new social media more strongly contributes to producing hate speech (Yazic1, 2016, p. 133). Studies on hate speech in new media shows prejudices containing the "us" and "them" attitude towards the Syrians and builds stereotypes about the Syrian refugees. Some research specifically examined the hashtag \#ülkemdesuriyeliistemiyorum (\#idontwantsyriansinmycountry) and the widespread hate speech in the new social media. Online media's hate speech against Syrians has the common denominator of describing the refugees as threats, invaders, criminals, and potential dangers. These hate and hostility discourses towards refugees provide ground for a collective nationalist identity (Taşdelen, 2020, p. 1). Furthermore, the topics include such allegations that Syrians abuse the Turkish state, "they receive a state salary," "the Syrians get T.C. (Turkish Republic's citizenship) to gain votes," "Syrians have the right to enter into the university without an exam" (Yanık, 2017). This discourse also describes refugees as threats to cultural values, economy, and security of the nation-state by being terrorists, rapists, thieves, molesters, gang members (Bozdağ, 2019; Sayımer, 2017). Some studies analyze hate speech against Syrian refugees in the local and mass media with similar findings about prejudices and the content. This discourse includes national self-glorification, superiority of Turkish culture and represents Syrians as an economic burden, social problem makers, thieves, crooks, mannerless, and not fitting in with Turkish habits (Alp, 2018; Göker, Keskin, 2015; Onay-Coker, 2019; Y1lmaz-Wilke, 2015).

Van Dijk (2003) sees scapegoating mechanisms as scapegoating yourself and scapegoating the other. In the cited research and studies, the refugees are seen as the scapegoats of the war and Turkey is stated as the scapegoat of the most affected country by the refugee flow from Syria. The news broadcasts increase this polarization between "us" and "them" (Göker, Keskin, 2015, pp. 254 255).

\section{THE RESEARCH QUESTIONS}

This study intends to contribute to the analysis of hate crime against Syrian migrants in Turkey by asking these questions:

\section{R.Q.1.) Which discourses are displayed in hate speech?}

R.Q.2.) Which discourses play a role in hate crime and what are the common denominators of hate crime and hate speech? 
R.Q.3.) Furthermore, how can hate crime, also inspired by hate speech, be contextualized within Derrida's concept of hos(ti) pitality?

\section{METHODOLOGY}

Different media sources provided data for the research questions on hate crime that includes hate speech, hate attacks, and hate murders. This paper analyzed the events with reference to the frame of hate speech and hate crime which refer to the discourse analysis of Van Dijk. Van Dijk's (2000) discourse analysis says that "discourses have ideologically based opinions." Ideological ideas are learned by "reading and listening to other group members" (p. 8). "Often, ideologies thus emerge from group conflict and struggle, and they thus typically pitch 'us' against 'them"' (Van Dijk, 2000, p. 8). This ideology constructs discourses in a polarization of "us" and "them" and they spread as a representation of the groups. Hate crime is produced and reproduced within the mass media and digital media which broadcasts the hate speech against the other and spreads it among civil society. Hate speech constructs "us" and "other" which is spread throughout the media and deepens the cleavage between "us" and "other" (Kuş, 2006, p. 99).

Van Dijk (2003) describes Critical Discourse Analysis (CDA) as focusing "on the ways [that] discourse structures enact, confirm, legitimate, reproduce, or challenge relations of power and dominance in society" (p. 353). Van Dijk's (2003) considers "racism (including antisemitism, xenophobia, and related forms of resentment against 'racially' or ethnically defined Others) is a complex system of social and political inequality that is also reproduced by discourse in general, and by elite discourses in particular" (p. 362). The racist discourse has rhetoric which "refers to ethnic inequality, racism or discrimination" (Van Dijk, 2000, pp. 58-59). Van Dijk (2003) sees discourse as action or practice in "everyday life, very much like power" (p. 12).

Van Dijk's (2003) discourse analysis considers macro and micro levels. Power, dominance, and inequality between social groups are terms typically belonging to a macro level of analysis. CDA connects the well-known "gap" between micro and macro approaches. The macro and micro level (and intermediary "meso levels") shape everyday interactions into a unified whole. While a racist speech in parliament can be a discourse at the micro level of social interaction in the specific situation of a debate, it also may enact or be an essential part of legislation or the reenactment of racism at the macro level (Yazic1, 2016, p. 354).

News reports of hate crime against Syrian migrants will be analyzed with reference to the discourse, ideology, power, and representation of hate speech at macro and micro levels according to CDA of Van Dijk. Syrians make the selected group of hate crime with reference to the frame of hos(ti)pitality of Derrida. Ideology, power, and representation of the other according to CDA are an outcome of hate speech contextualized in the hate crime expressed as hate protests and hate murder.

\section{FINDINGS}

In this research, I analyzed 17 hate crime cases occurring between 2014 and 2020. In 2014, six hate crimes took place. One happened in May, two happened in July and four happened in August 2014. One of the six cases was a hate crime, five cases involved hate protests against Syrians and two cases were an attack of Syrians on the state. Hate mobilizations occurred in the cities of Ankara, Gaziantep, İzmir, Şanlıurfa, and Kahramanmaraş. Two cases happened in Gaziantep, the others happened in İzmir, Kahramanmaraş and Şanlıurfa. The hate crime in Ankara was assumed to have resulted from Syrian refugees arguing with Turks that resulted in stoning and burning of the Syrians' house. That case resulted in many injuries including a police officer. Groups mobilized hate protests such as that involving 1000 people living in Kahramanmaraş. In Izmir, 200 shoemakers protested because of Syrians possibly threatening their jobs. The main reasons declared for the protests included rising rents, rising unemployment, Syrians working cheaper than Turks, assumption of sexual harassment, and so on. The mainstream news noted the protesters claim that Syrians were a burden and threat for the nation and for the Turkish society. The protesters had slogans such as "We don't want any Syrians!" and also attacked unknown Syrians on the street. 
In July and in August 2018, two disputes between Syrians and Turks occurred in the bread lines in Şanliurfa that resulted in the injuries of seven Syrians for unknown reasons. In 2019, a hate mobilization against Syrians resulted from an alleged sexual harassment of a Turkish girl by a Syrian boy. In another case, the residents in Adana protested about the presence of Syrians. The reason for that protest resembled the hate protests in cities Gaziantep, İzmir, Şanlıurfa, and Kahramanmaraş in 2014; the protestors did not want Syrians in the city because the Syrians had been made into a hated and unliked group of strangers. In one case, a Syrian was injured; in the other case, the shops of Syrians were damaged.

Eight cases of hate crime happened in 2020, four in August, two in July, one in June, and one in March. Two hate crime cases took place in Hatay, while two took place in Istanbul within the Zeytinburnu and Küçükçekmece districts, one case took place in Adana, and the other three cases happened in Mardin, Bursa and Kahramanmaraş. After 34 Turkish soldiers died in a military operation in İdlib, Syria, a crowd of Turkish locals in Hataya initiated a hate protest against Syrians refugees and damaged their shops and houses. In another hate crime in Hatay, a neighbor murdered a two-year-old Syrian child. Other hate crimes resulting in murder included Hamza Acan in Bursa (July 2020), Muayy1d El Milhım in Mardin (August 2020), Abdulkadir Davud in Istanbul Zeytinburnu (August 2020), and Selahattin Elhasan Elcunid in Adana (August 2020). The murder cases of Abdulkadir Davud and Selahattin Elhasan Elcunid were obviously linked to hate crime. Two other cases probably also related to the feelings of hate, xenophobia, and racism because the perpetrators just murdered so "easily" without any concrete reason other than that the victims were Syrians. In August 2020 in Küçükçekmece, the perpetrator's statements clearly revealed that it was a racist, xenophobic, and hate-motivated attack with physical injuries. Table 1 in the appendix summarizes the findings.

The first and second research questions "Which discourses are displayed in hate speech?" and "Which discourses play a role in hate crime and what are the common denominators of hate crime and hate speech?" are answered with reference to Van Dijk's macro level of analysis.

At the macro level of analysis, Syrians are forced to "live on the threshold" because of structural inequality and precarious situation resulting from their "temporary protection" legal status. The hate mobilizations against Syrians have the same motives as the hate speech claiming that Syrians represent a threat deepening the structural inequality within the society. At the macro level of analysis, the Turkish flags carried in the protests against Syrians reveal the role of Turkish nationalism. At the same time, the Turkish military intervention in the Syrian war paves the way for mobilization against Syrians. Thus, Turkish nationalism appears at the macro level as an important dimension of the existing racism and xenophobia against Syrians. The news report on hate crime of Syrians murdered without any reason. Some reports indicate hate speech such as "Fuck off Syrians," "I will kill all Syrians I will encounter." Hate crime with murder can be interpreted as a consequence of hate speech in which the hated other awakens xenophobic, racist feelings in the gaze of the perpetrator.

The third research question, "How can hate crime which includes the motives of hate speech, be contextualized within Derrida's concept of hos(ti)pitality?" is to be contextualized within the hate speech and hate crime as an outcome of hate speech at macro and micro level of analysis. The motives within the hate protests state the hostility of the urban residents against Syrians and the expectation that the guest must eventually leave the city but can remain only with limited guest rights. The speech of victims of hate crime also emphasize their temporality as guests and the Muslim community as the common denominator which should provide hospitality instead of hostility. The survivor's speech reveals that hate murder and hate attack is just related to their group entity as "others".

\section{DISCUSSION AND CONCLUSION}

Derrida's concept of hos(ti)pitality inherits the concept of hospitality simply as invader and the host can decide on the threshold about the person whom the host lets enter the home but who can become hostage. The "we" (us) and "other" (them) distinction about the host and guest relates to feelings of insecurity, unsafety, losing a home, threats from the other, and not feeling at home anymore. The conditional hospitality of the other is contained and inherited within the host's discourse about the guest, 
which is also reflected in the hate speech of rightwing politicians and in the tolerance speech of Fatma Şahin about the protests in Gaziantep, in which she underlined the dimension of the guest instead of the refugee ("Suriyeli istemiyoruz". Gaziantepliler "Suriyelileri istemiyoruz!”, 2014 July 07. Sözcü). The hate speech of rightwing politicians such as "iyi parti" (Uğur Mumcu Araştırmacı Gazetecilik Vakfı, 2018) are especially instructive in their unapologetically frank declarations on social media and elsewhere. They make all of the usual arguments such as Syrians are threats to social safety and national state's identity, an economic burden because they live at the costs of Turks. The political actors of iyi parti post this hate speech about Syrians in the social media (Meral Akşener'den 1rkçı çıkış: Suriyelileri geri göndereceğiz: Akșener'in gündeminde Suriyeli sı̆gınmacılar vardı, 2018 November 20. Evrensel). The governors also have this "guest/host", "us/them" speech and "to make the guests know the limits of their freedom" and "they shouldn't live on our costs." Can (2019) reports that in the summer of 2019, two banners appeared at the entrance of a beach in the city of Sinop on the Black Sea coast: "Those who don't fight for their country are not allowed on our beach" and "Long live the Turkish race." After the banners were widely publicized and criticized on social media, the Sinop governor issued a statement saying that action was taken to remove the banner (sic) as soon as it was noticed, and that the prosecutor's office had decided no legal action to be necessary (Can, 2019). In this case, the local authorities stopped short of allowing the action of the business owner that had hung the banner yet did not penalize him. A similar act of discrimination happened in Mudanya and Antalya not just with the collusion, but at the actual initiative of the local government. In his June 2019 article for Diken, Göktaş (2019) reports that the Mudanya and Antalya municipalities had prohibited Syrians from entering the beaches. Municipal police acted against Syrian refugees after locals complained of being bothered by them: at the order of the governor, the refugees' tents were removed from the area and the constables kept watch to prevent reentry. Göktaş (2019) reported that the Mudanya governor Hayri Türkyılmaz tweeted: "While our economy is waning and our mothers shed tears for our dying children, they are living a life of ease and disturbing our people." Furthermore, in a comment under his own tweet Türkyılmaz linked to an article in Artı Gerçek entitled "The constables are keeping watch the Syrians will not enter!" which described the governor's actions in highly discriminatory and inflammatory language: "The Mudanya governor rescued Mudanya's shores from occupation by Syrians" ("Mudanya'da Belediye Sahili”, 2019).

Syrians are seen as guests that should know their temporary conditions; at the same time, they cause hostility because of their guest status (Lortoğlu, 2017, p. 74). As with the hate speech in the social media, mass and local media state the guest should recognize itself as guest, should receive only what the host gives to the guest and the host protects its authority and limits the "gifts it provides to the guest" (Lortoğlu, 2017, p. 75).The mobilization of local residents against Syrians, hate speech within the protests against Syrians, hate speech of the politicians, hate crime which leads to hate murder have their roots within the double scapegoating such as the Syrians are scapegoats of the war and Turks are the generous host, at the same time Turks and Turkish nation are the scapegoats of the Syrian refugee flow that affect the national security. With reference to Van Dijk's ideology of the group conflict, the perception of "us against them" (Van Dijk, 2000, p. 8) exists and political discourses reflect power relations of the elites and "discourse structures enact, confirm, legitimate, reproduce, or challenge relations of power and dominance in society" (Van Dijk, 2003, p. 353). The common motives of hate speech and hate crime are to identify the other as a threat for the nation at many levels, such as threatening the national body with the birth of not-Turkish children, to abuse the state and to be a burden for the nation, including decreasing salaries, stealing the jobs, increasing the rents of the flats, increasing the density of the cities. When Turkish soldiers die in Syria, then the fear of an approaching war increases Turkish nationalism and the hostility against Syrians.

Hospitality discourse that started by welcoming the Muslim family as guests, has turned at the level of civil society and rightwing politicians towards a discourse of burden, threat, and feeling that the host loses status as master of the house. Syrian migrants and refugees murdered or attacked just because of their race and ethnic backgrounds can be contextualized within the hate-crime definition that the victim is targeted because of race and group identity. AKP's ümmet policy and the reference to Islam as a common identity underpinned the initial open-door policy for the refugees and provided a basis for some level of inclusion. However, the refugees' legal status under the Temporary Protection Regulation and the lack of an 
integration policy have trapped them into a permanent threshold status, within which they are exposed to the ambivalent feelings of the hosts as potentially unwanted guests, liable at any time to be re-imagined as hated, fearsome, disgusting others. For the Syrian refugees, the nation never becomes a home, whereas for the Turkish citizens it transforms into an uncanny place where the presence of strangers does not allow one to feel quite at home. The hate speech and hate crime against the Syrian refugees in Turkey are rooted in this perception of an incursion into one's home. Here, the encounter with the other turns host into hostage. The guest becomes the hated other and enemy of the nation.

\section{REFERENCES}

Alp, H. (2018, January). Suriyeli sığınmacılara yönelik ayrımcı ve ötekileştirici söylemin yerel medyada yeniden üretilmesi [The reproduction of the discriminative and othering discourse against Syrian refugees within the social media]. Karadeniz Teknik Üniversitesi İletişim Fakültesi Dergisi, 15, 22-37.

Asulis. (2018). Medyada Nefret Söylemi ve Ayrımcı Söylem 2018 Raporu [The 2018 report of hate and discrimination speech within the media]. Retrieved from https:/hrantdink.org/tr/asulis/yayinlar/72-medyada-nefret-soylemi-raporlari/2003-medyadanefret-soylemi-ve-ayrimci-soylem-2018-raporu

Asulis. (2019). Medyada Nefret Söylemi ve Ayrımcı Söylem 2019 Raporu [The 2019 report of hate and discrimination speech within the media]. Retrieved from https://hrantdink.org/attachments/article/2665/Nefret-soylemi-ve-Ayr\%C4\%B1mc\%C4\%B1Soylem-2019-Raporu.pdf

Atalay, O. (2014, August 19). Suriyeli muhacirler bizim kardeşimizdir [Syrian refugees are our brothers and sisters]. Akit. Retrieved from https://www.yeniakit.com.tr/yazarlar/osman-atalay/suriyelimuhacirler-bizim-kardesimizdir-7332.html

Balci, B. (2014, February 6). Syria Drawn into Turkey's Crisis. Carnegie Endowment for International

Balkılıç, Ö., \& Teke Lloyd, F.A. (2020). Akp'nin Suriyeli göçmen söylemini Türkiye'nin jeopolitik senaryosuyla birlikte okumak [Reading the AKP's Discourse on Syrian Migrants from the Lens of Turkey's Geopolitical Script (sic)]. Alternatif Politika, 12(3), 542-564.

Bati, M., \& de Vries, H. (2000). Of Hospitality. Anne Dufourmantelle invites Jacques Derrida to respond. Stanford, California: Stanford University Press.

Benveniste, E. (1973). Indo-European Language and Society. London: Faber and Faber.

Binark, M., \& Çomu, T. (2012, January 20). Sosyal Medyanın Nefret Söylemi için Kullanılması Ífade Özgürlüğ̈̈ değildir! [Using social media for the hate crime is not freedom of speech!]. Yenimedya. Retrieved from https://yenimedya.wordpress.com/2012/01/20/sosyal-medyaninnefret-soylemi-icin-kullanilmasi-ifade-ozgurlugu-degildir/

Bozdağ, Ç. (2019). Bottom-up nationalism and discrimination on social media: An analysis of the citizenship debate about refugees in Turkey. European Journal of Cultural Studies, 23(5), 1-19. https://doi.org/10.1177/1367549419869354

Can, D.O. (2019, July 10). Valilik harekete geçti, "Suriyeliler plaja giremez" pankartı kaldırıldı [The governor takes action: "Syrians cannot enter" sign removed from beach]. Kaçkar. Retrieved from http://kackartv.com.tr/valilik-harekete-gecti-suriyeliler-plaja-giremez-pankarti-kaldirildi/17027/

CNNTürk.com. (2014, August 9). Hamallar sopalarla Suriyelileri kovaladı [Porters armed with sticks chase Syrians away]. Retrieved from https://www.cnnturk.com/haber/turkiye/hamallar-sopalarlasuriyelileri-kovaladi

Çoban, F. (2015). Bir giriş: Derrida'nın hayaletlerinden Marks'ın hayaletlerine [An introduction: From Derrida's ghosts to Marx's ghosts]. SDÜ Sosyal Bilimler Dergisi, 35, 147-174.

Council of Europe Committee of Ministers. Recommendation No. R (97) 20 of the Committee of Ministers to Member States On "Hate Speech" (Adopted by the Committee of Ministers on 30 October 1997 at the 607th meeting of the Ministers' Deputies) 
Cumhuriyet. (2020, March 01). Maraş'ta Suriyelilerin iş yeri ve evlerine saldırı. [Attack on the houses of the Syrians in Maraş] Retrieved from https://cumhuriyet.com.tr/video/marasta-suriyelilerin-isyeri-ve-evlerine-saldiri-1724350

Derrida, J. (1998). Monolingualism of the Other or The Prosthesis of Origin. Stanford, California: Stanford University Press.

Derrida, J. (2000a). Hostipitality. Angelaki: Journal of the Theoretical Humanities, 5(3), 3-18. https://doi.org/10.1080/09697250020034706

Derrida, J. (2000b). Of Hospitality. Anne Dufourmantelle invites Jacques Derrida to respond. Stanford, California: Stanford University Press.

Derrida, J. (2001). On Cosmopolitanism and Forgiveness. London and New York: Routledge Catherine.

Erdoğan, M. (2017). Suriyeliler Barometresi 2017: Suriyelilerle Uyum İçinde Yaşamın Çerçevesi [The Syrian barometer 2017: The frame of living with the Syrians in harmony]. Ankara: Hacettepe Üniversitesi Göç Araştırmaları Merkezi.

Evrensel. (2018, November 20). Meral Akşener'den ırkçı çıklş Suriyelileri geri göndereceğiz: Akşener'in gündeminde Suriyeli sığınmacılar vardı [Racist remark by Meral Akşener: we will send the Syrians back: Syrian refugees are on Akşener's agenda]. Retrieved from:

https://www.evrensel.net/haber/366386/meral-aksenerden-irkci-cikis-suriyelileri-gerigonderecegiz

Evrensel. (2020, August 17). Zeytinburnu'nda mültecilere kurşun: Suriyeli işçi Abdulkadir Davud hayatın kaybetti. [Shooting at the refugees in Zeytinburnu: The Syrian worker Abdulkadir Davud lost his life]. Retrieved from https://www.evrensel.net/haber/411847/zeytinburnunda-multecilerekursun-suriyeli-isci-abdulkadir-davud-hayatini-kaybetti

Evrensel. (2020, August 24). Pompalı tüfekle öldürülen Suriyeli iş̧̧inin yakını: Bombadan kaçtık burada ölüyoruz [The relative of the Syrian worker has been murdered with a pump rifle: We escaped from the bomb and we die in here]. Retrieved from https://www.evrensel.net/haber/412286/pompali-tufekle-oldurulen-suriyeli-iscinin-yakinibombadan-kactik-burada-oluyoruz

Evrensel.net. (2019, June 30). İstanbul İkitelli'de taciz iddiası Suriyelilere yönelik ırkçı saldırıya dönüştü. [The claim about the Syrians sexual harassment in İstanbul İkitelli turned into a racist attack against Syrians] Retrieved from https://www.evrensel.net/haber/382173/istanbul-ikitellide-taciziddiasi-suriyelilere-yonelik-irkci-saldiriya-donustu

Fotou, M. (2016). Ethics of hospitality: Envisaging the stranger in the contemporary world (Doctoral dissertation). The London School of Economics and Political Science, London, United Kingdom. Retrieved from http://etheses.1se.ac.uk/3403/1/Fotou_Ethics_of_Hospitality.pdf

Gazete Karınca. (2020, July 17). Suriyeli Hamza Ajan, dört kişinin tacizine uğrayan bir kadını savunurken öldürüldü [Syrian citizen Hamza Ajan killed while protecting a woman from being harassed by four people]. Retrieved from https://gazetekarinca.com/2020/07/suriyeli-hamza-ajandort-kisinin-tacizine-ugrayan-bir-kadini-savunurken-olduruldu/

Genç, H.D., \& Özdemirkıran-Embel, Ö. (2019). Paradoxical Perceptions on Syrians' Forced Migration to Turkey: A Case Study of Istanbul Muhtars. Alternatif Politika, 11(1), 168-191.

Göker, G., \& Keskin, S. (2015, Autumn). Haber Medyası ve Mülteciler: Suriyeli Mültecilerin Türk Yazılı Basınındaki Temsili [News Media and Refugees: Representation of Syrian Refugees in Turkish Press]. İletişim Kuram ve Araştırma Dergisi, 41, 229-256.

Göktaş, K. (2019, June 9). CHP ve Suriyeliler: Mudanya'da ne oldu? CHP ne diyor? [CHP and the Syrians. What happened in Mudanya? What does CHP say?] Diken. Retrieved from http://www.diken.com.tr/chp-ve-suriyeliler-mudanyada-ne-oldu-chp-ne-diyor/

Haberercis.com.tr. (2020, June 09). Komşusu 2 yaşındaki Suriyeli çocuğu katletti. [Neighbour murdered a 2-year-old Syrian child] Retrieved from Komşusu 2 yaşındaki Suriyeli çocuğu katletti İletişim

Haberler.com. (2014, August 8). Ayakkabıcılar sitesinde Suriyeli işçi isyanı. [The Syrian workers' upheaval in the Ayakkabicilar district] Retrieved from https://www.haberler.com/ayakkabicilarsitesinde-suriyeli-isci-isyani-6379065-haberi/ 
Haberler.com. (2014, August 14). Ayakkabıcılar Sitesinde Suriyeli İşçi İsyanı [Ayakkabıcılar Compound rocked by protest against Syrian workers]. Retrieved from http://www.haberler.com/ayakkabicilar-sitesinde-suriyeli-isci-isyani-6379133-haberi/

Hurriyet.com.tr. (2018, August 26). Firında ekmek sırası kavgası: 7 yaralı 7 gözaltı [The quarrel for bread in the bakery: 7 people are injured 7 people are under custody]. Retrieved from Samsun'da ırkçı grubun saldırısında 16 yaşındaki Suriyeli Eymenh Hammamı öldürüldü - Yeryüzü Postası (yeryuzupostasi.org)

İlerihaber.org. (2020, July 30). Hatay'da ırkçı saldırı: Suriyeli 2 genç öldüresiye dövüldü [A racist attack in Hatay: 2 Syrian young people are being beaten deadly]. Retrieved from https://ilerihaber.org/icerik/hatayda-irkci-saldiri-suriyeli-2-genc-olduresiye-dovuldu-115726.html

İnceoğlu, Y., \& Sözeri, C. (2012). "Nefret Suçlarında Medyanın Sorumluluğu: "Ya Sev Ya Terk Et Ya Da..." [The Responsibility of the Media in Hate Crime: "Love, Leave or..."]. In Y. Inceoğlu (Ed.), Nefret Söylemi ve/veya Nefret Suçları [Hate Speech and/or Hate Crime]. Ayrıntı Yayınları, Istanbul.

İnsan Hakları Derneği [Human Rights Foundation]. (2020, September 2). Türkiye'de Nefret Suçlarl ve Son Dönemde Yaşanan Irkçı Saldırlar Özet Raporu. [Summary of hate crimes in Turkey and the hate crime report in the last period]. Retrieved from https://www.ihd.org.tr/wpcontent/uploads/2020/09/20200922_NefretSucuIrkciSaldirilarRaporu-OrnekVakalar.pdf

Kant, I. (1970). Perpetual Peace. In H. Reiss (Ed.), Kant's Political Writings. Cambridge: Cambridge University Press.

Karaveli, H. (2013, October 7). Erdogan Stokes the Sectarian Fires. New York Times. Retrieved from http://www.nytimes.com/2013/10/08/opinion/erdogan-stokes-the-sectarian-fires.html?_r=0

Kirisçi, K. (2014). Syrian refugees and Turkey's challenges: Going beyond hospitality. Washington, DC: Brookings.

Koca, B.T. (2016, May). Syrian refugees in Turkey: from "guests" to "enemies"? New Perspectives on Turkey, 54, 55-75. https://doi.org/10.1017/npt.2016.4

Kordvani, A. (2006). Hospitality, Politics of Mobility, and the movement of service suppliers under the gats. Melbourne Journal of International Law, 7(1), 74-103. Retrieved from https://law.unimelb.edu.au/mjil/issues/issue-archive/71

Kuş, O. (2006). Dijital nefret söylemini anlamak: Suriyeli mülteci krizi örnek olayı bağlamında BBC World service facebook sayfasına gelen yorumların metin madenciliği tekniği ile analizi [Understanding the digital hate speech: The analysis of the comments coming to the BBC World service page of Facebook in the example of the Syrian refugee crises with the method of text mining.] Ístanbul Üniversitesi İletişim Fakültesi Dergisi, 2016(II), 97-121. DOI:

10.17064/iuifd.289373

Lazarev, E., \& Sharma, K. (2017). Brother and Burden: An Experiment on Reducing Prejudice Toward Syrian Refugees in Turkey. Political Science Research and Methods, 5(2), 20--219. https://doi.org/10.1017/psrm.2015.57

Levin, J., \& McDevitt, J. (2002). Hate crimes revisited: American's war against those who are different. Boulder, CO: Westview.

Levin, J., \& Rabrenovic, G. (2001). Hate crimes and ethnic conflict: A comparative perspective. American Behavioral Scientist, 45, 574-755.

Lortoğlu, C. (2017). Suriyeli Mültecilerin "Misafir" Olma Haline Misafirperverlik Hukuku ve Etiği Açısından Bakış [Looking at the "Being Guest" of the Syrian Refugees from the Aspect of the Guest Right and Ethics]. Insan\&insan, 4(11), 54-80. https://doi.org/10.29224/insanveinsan.289156

Makris, S. (2006). Politics, Ethics and Strangers in the 21st century: Fifteen critical reflections on Jacques Derrida's concept of hos(ti)pitality. Theoria and Praxis, 5(1), 1-21.

Mardin Life. (2020, August 14). Silahla vurularak öldürülen Suriyeli işçi defnedildi. [The Syrian worker murdered with the gunshot has been buried]. Retrieved from Silahla vurularak öldürülen Suriyeli işçi defnedildi | 
Milliyet. (2019, September 11). Adana'da Suriyeli Gerginliği. Suriyelileri istemeyen mahalle sakinleri eylem yaptt. [The Syrians tension in Adana. The district residents in Adana don't want Syrians made a demonstration] Retrieved from https://www.milliyet.com.tr/milliyet-tv/adanada-suriyeligerginligi-video-4648185

Milliyet. (2014, August 13). Gece sokakta Suriyeli avına çıkıldı [Hunting of Syrians in the night]

Retrieved from https://milliyetciataturkpartisi.blogspot.com/2014/08/gece-sokakta-suriyeli-avnackld.html

Naas, M. (2006). Jaques Derrida ve konukseverlik sorusu [Jacques Derrida and the question of hospitality]. Cogito Dergisi Özel Sayısı (Derrida: Yaşamı Yeniden Düşünürken), 47-48, 240257.

Onay-Coker, D. (2019). The representation of Syrian refugees in Turkey: A critical discourse analysis of three newspapers. Journal of Media \& Cultural Studies, 33(3), 369-385.

https://doi.org/10.1080/10304312.2019.1587740

Ortadoğu Stratejik Araştırmalar Merkezi (Center for Middle Eastern Strategic Studies). (2015). Effects of

Özden, S. (2013). Research Report (05). Migration Policy Centre. "Syrian Refugees in Turkey".

Retrieved October 8, 2015, from http://www.migrationpolicycentre.eu/docs/MPC-RR-201305.pdf

Ozturk, Y.E., \& Guler, H.I. (2019, August 1-10). Discourses of exclusion on Twitter in the Turkish Context: ülkemdesuriyeliistemiyorum (\#idontwantsyriansinmycountry). Discourse, Context \& Media. Retrieved from www.elsevier.com/locate/dcm_DOI: 10.1016/j.dcm.2020.100400

Parekh, B. (2006). Hate speech. Is there a case for banning? Wiley Online Library, 12(4), 213-223. https://doi.org/10.1111/j.1070-3535.2005.00405.x

Peace. Retrieved October 8, 2015, from http://carnegieendowment.org/syriaincrisis/?fa $=54445$

Posta.com.tr. (2014, July 13). Kahramanmaraş'ta 'Suriyeli istemiyoruz' eylemi. ['We don't want Syrians' demonstration in Kahramanmaraş]. Retrieved from https://www.posta.com.tr/kahramanmarastasuriyeli-istemiyoruz-eylemi-235987

Recep Tayyip Erdoğan. (2013, May 5). Twitter Web Client. Retrieved from (18) Recep Tayyip Erdoğan no Twitter: "Allah'ın yardımı ne zaman diye soran Suriyeli kardeşlerime, şunu söylüyorum Hiç kuşkusuz Allah'ın yardımı yakındır." / Twitter.

Sayımer, İ. (2017). Syrian refugees as victims of fear and danger discourse in social media: A Youtube analysis. Global Media Journal TR Edition, 8(15).

Şirin-Ö.A., \& Deniz G. (2015). Vulnerability leading to mobility: Syrians' exodus from Turkey. Migration Letters, 12(3), 251-262. 10.33182/ml.v12i3.278

Sözcü. (2014, July 7). "Suriyeli istemiyoruz'”. Gaziantepliler "Suriyelileri istemiyoruz!' eylemi gerçekleştirdi. ['We don't want Syrians"'. The citizens of Gaziantep made "We don't want Syrians!" protests.] Retrieved from https://www.sozcu.com.tr/2014/gunun-icinden/suriyeliistemiyoruz-eylemi-yaptilar-550117/

Stocker, B. (2006). Derrida on Deconstruction. London and New York: Routledge.

Sullaway, M. (2004). Psychological perspective on hate crime laws. Psychology, Public, Policy, and Law, 10, 250-292. DOI: 10.1037/1076-8971.10.3.250

Sun, K. (2006). The legal definition of hate crime and the hate offender's distorted cognitions. Mental Health Nursing, (27), 597-604. 10.1080/01612840600642877

T.C. İçişleri Bakanlığg Göç İdaresi Genel Müdürlülüğü (2021, March 17). Geçici Koruma. Yıllar Göre Geçici Koruma Kapsamındaki Suriyeliler. Retrieved from GEÇİCi KORUMA (goc.gov.tr)

T24.com.tr. (2014, May 8). Ankara'da Suriyelilerin evleri yakıldı. Ankara'da Suriyeliler ile mahalleliler arasında kavga çıktı. [In Ankara, a house of Syrians has been burned. Tension between Syrians and local residents in Ankara]. Retrieved from https://t24.com.tr/haber/ankarada-suriyelilerinevleri-yakildi, 257860

T24.com.tr. (2020, August 2). Küçükçekmece'de Suriyeli işçiye ırkçı saldırı: Şüpheliler 5 gündür yakalanmadi. [Attack of Syrian worker in Küçükçekmece. The suspects have not been arrested in 
the past 5 days]. Retrieved from https://t24.com.tr/haber/kucukcekmece-de-suriyeli-isciye-irkcisaldiri-supheliler-5-gundur-yakalanmadi,894364

T24.com.tr. (2020, September 15). Samsun'da 16 yaşındaki Suriyeli Eymenh Hammamı'nın öldürüldüğ̈̈ anlara ait kamera kayıtları ortaya çıktı. "Biz 9 yıldır Samsun'da yaşlyoruz. Kimseyle sorun yaşamadık." [Video recordings revealed in Samsun show the moments of the murder of the 16 year-old Syrian Eymenh Hammam. "We have lived in Samsun for the past nine years. We didn't have any problem with anybody.']. Retrieved from https://t24.com.tr/video/samsun-da-16yasindaki-suriyeli-eymenh-hammami-nin-olduruldugu-anlara-ait-kamera-kayitlari-ortayacikti,32384

Taşdelen, B. (2020). Twitter'da suriyeli mültecilere karşı çevrimiçi nefret söylemi; \#suriyelileriistemiyoruz. Gümüşhane Üniversitesi Sosyal Bilimler Enstitüsü Elektronik Dergisi, 11(2), 562-575.

the Syrian Refugees on Turkey. Retrieved from https://www.tesev.org.tr/en/research/effects-ofthe-syrian-refugees-on-turkey/

Toprak, V. (2019, November 8). Bakan son rakamı açıkladı: İşte Türkiye'deki yabancı sayısı [Minister reports latest figures: Find out the number of foreigners in Turkey]. Sözcü. Retrieved from https:/www.sozcu.com.tr/2019/gundem/bakan-son-rakami-acikladi-iste-turkiyedeki-yabancisayisi-5438839/

Uğur Mumcu Araştırmacı Gazetecilik Vakfı (2018). Retrieved from http://www.umag.org.tr/tr/ana-sayfa

UNHCR Türkiye. (n.d.). UNHCR Türkiye İstatistikleri [The Turkish statistics of UNHCR] Retrieved from https://www.unhcr.org/tr/unhcr-turkiye-istatistikleri

Van Dijk, T. (2003). Critical Discourse Analysis. In D. Schiffrin., D. Tannen, \& E.H. Hamilton (Ed.), The Handbook of Discourse Analysis (pp. 352-372). Oxford: Blackwell Publishing.

Van Dijk, T.A. (2000): Ideology and discourse. A Multidisciplinary Introduction. Pompeu Fabra University, Barcelona.

Yanık, A. (2017). Sosyal Medyada Yükselen Nefret Söyleminin Temelleri. Global Media Journal TR Edition, 8(15), 364-383.

Yazıcı, T. (2016). Yeni medyanın nefret dili: Suriyeli mültecilerle ilgili ekşi sözlük örneği. Global Media Journal TR Edition, 7(13), 57-78.

Yilmaz-Wilke, T. (2015). Türkiye'nin 'Misafirleri': Medyada 'Suriyelilerin' Temsili. In Medyanın Milliyetçiliği: Milliyetçiliğin Medyası (pp. 1-25). Derin Yay.

Yurtseverlik. (2019, June 9). Mudanya'da belediye sahili Suriyelilere kapattı: Çocuklarımı şehit olurken onların sefa içinde yaşamalarına, insanımızı rahatsı etmelerine tahammül edemeyiz [Beach closed off to Syrians by the Mudanya municipality: They are living a life of ease and bothering our people even as our children die as martyrs; we won't stand for that]. Retrieved from https://www.yurtseverlik.com/mudanyada-belediye-sahili-suriyelilere-kapatti-cocuklarimiz-sehitolurken-onlarin-sefa-icinde-yasamalarina-insanimizi-rahatsiz-etmelerine-tahammuledemeyiz.html 


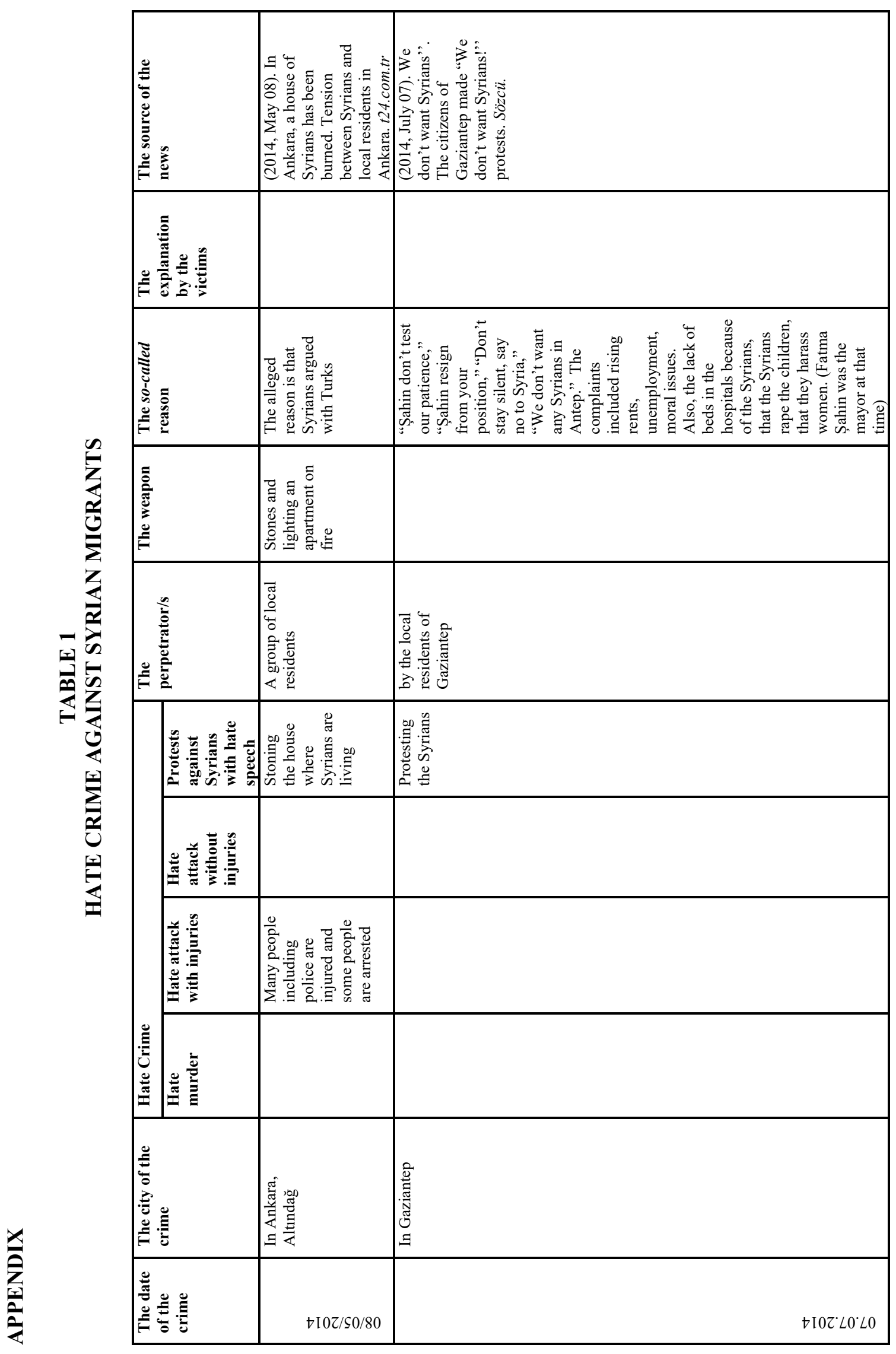

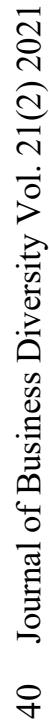




\begin{tabular}{|c|c|c|c|}
\hline 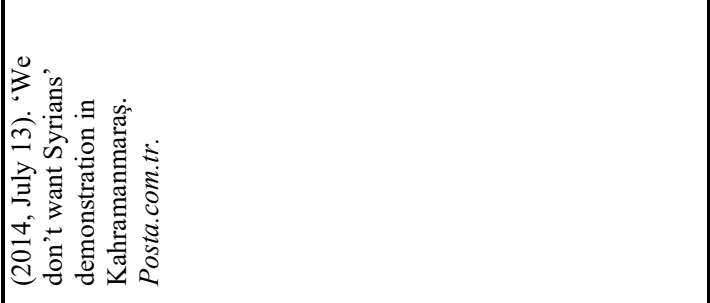 & 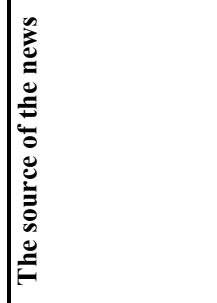 & 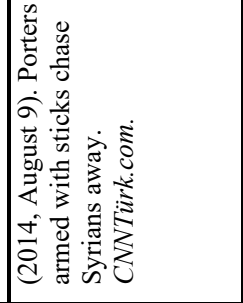 & 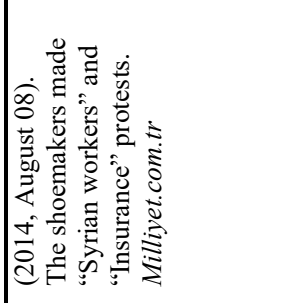 \\
\hline 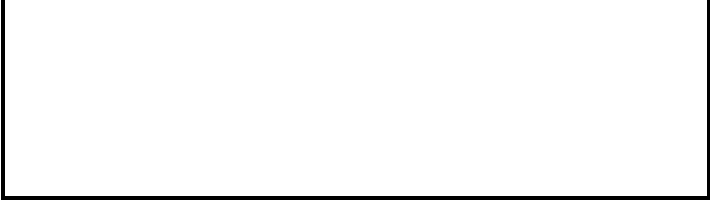 & 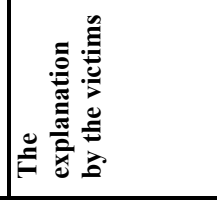 & & \\
\hline 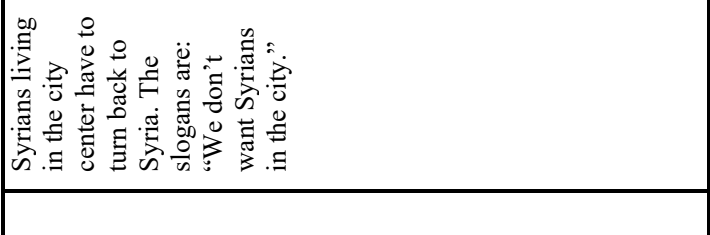 & 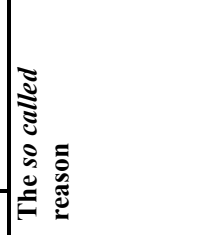 & 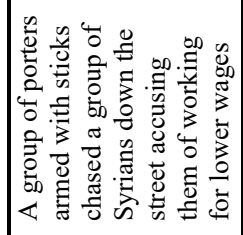 & 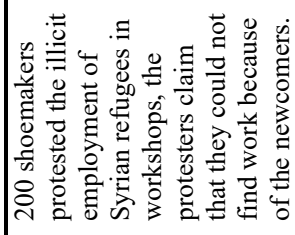 \\
\hline & 竞 & $\frac{n}{3}$ & \\
\hline 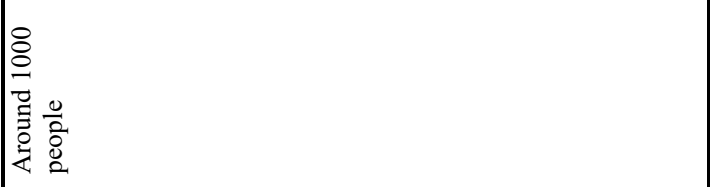 & | & 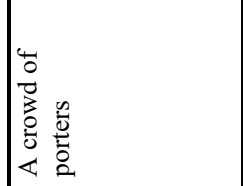 & 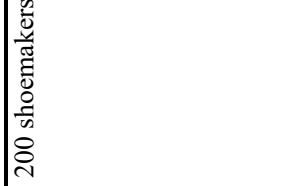 \\
\hline 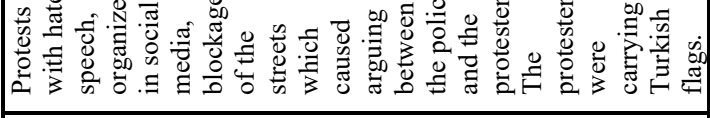 & 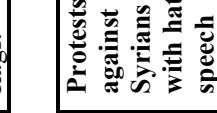 & 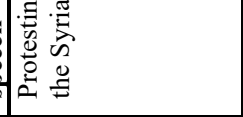 & \\
\hline & 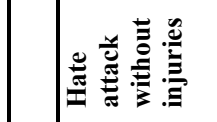 & & \\
\hline 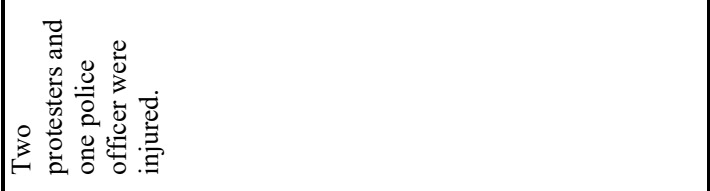 & 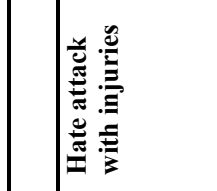 & & \\
\hline & 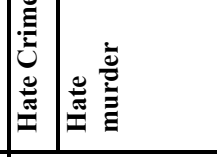 & & \\
\hline 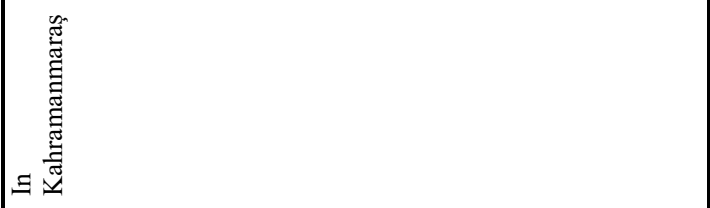 & 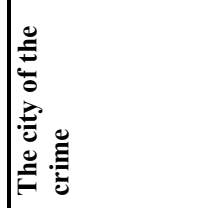 & $\mid$ & 暜 \\
\hline$\forall \sigma_{0}<0^{\circ} \varepsilon I$ & 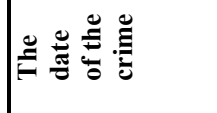 & $t \mid 0 \tau 80^{\circ} 60$ & $t 10 z^{\prime} 80^{\circ} \mathrm{tl}$ \\
\hline
\end{tabular}




\begin{tabular}{|c|c|c|}
\hline 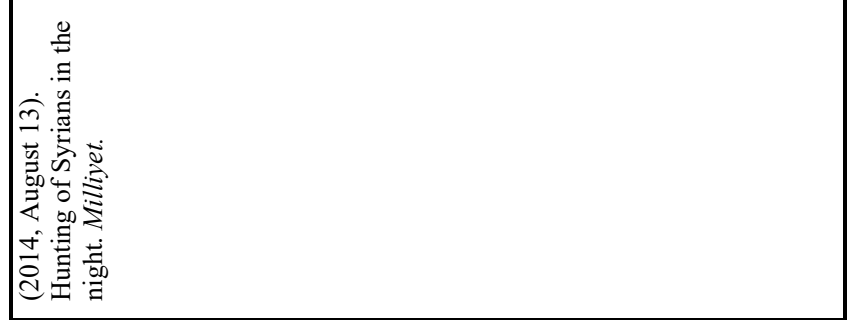 & 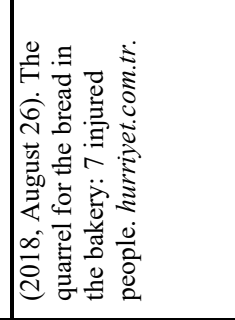 & 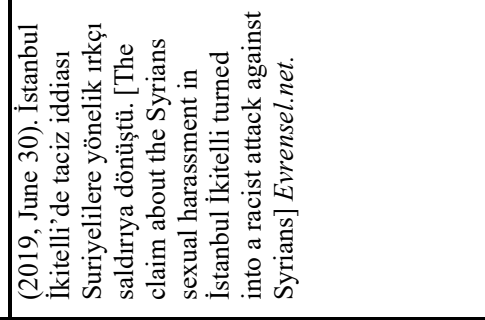 \\
\hline 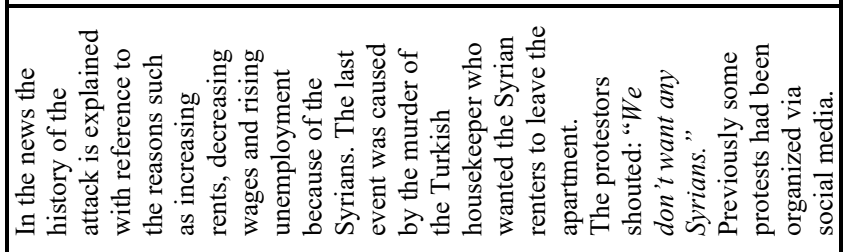 & 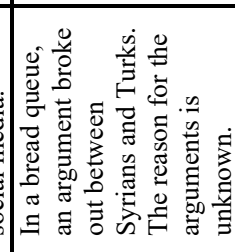 & 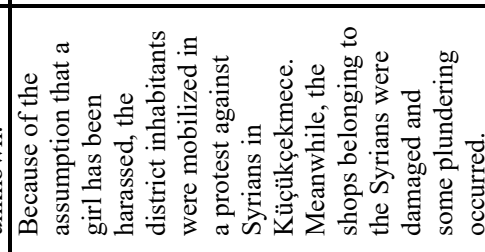 \\
\hline & 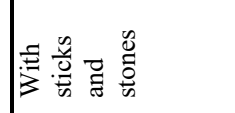 & \\
\hline 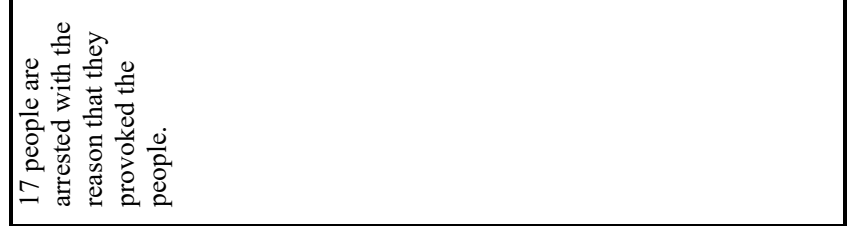 & 总 & \\
\hline & & 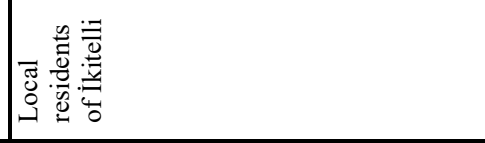 \\
\hline 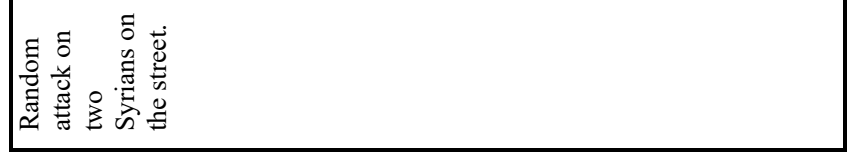 & & \\
\hline 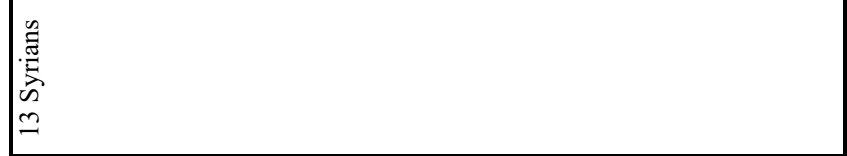 & 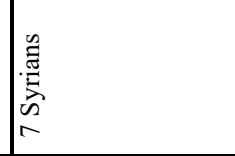 & \\
\hline $\mid$ & 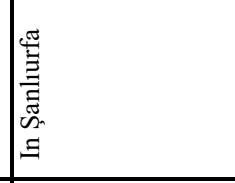 & 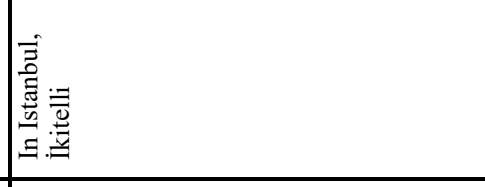 \\
\hline$t \mid 0 \tau-80^{\circ} \varepsilon 1$ & $810 \tau^{2} 80^{\circ} 9 z$ & $610 \tau^{\circ} 90^{\circ} 0 \varepsilon$ \\
\hline
\end{tabular}




\begin{tabular}{|c|c|c|c|}
\hline 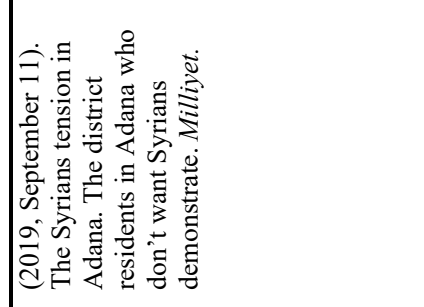 & 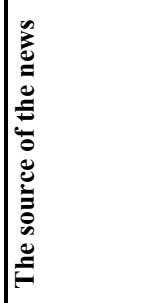 & 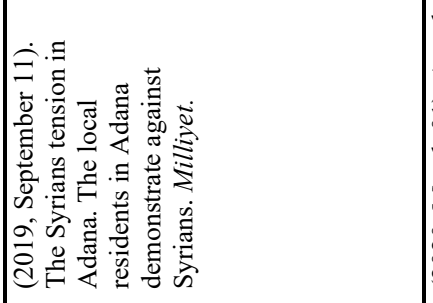 & 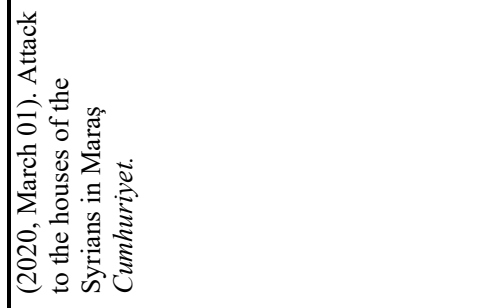 \\
\hline & 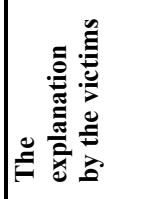 & & 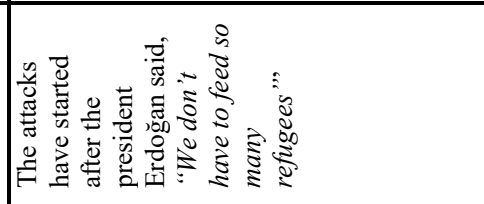 \\
\hline 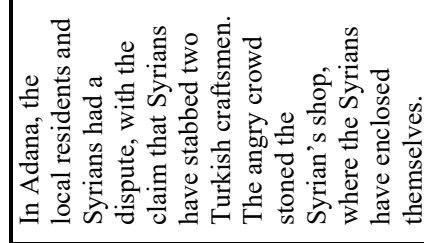 & 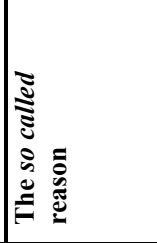 & 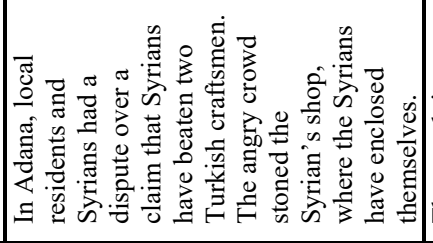 & 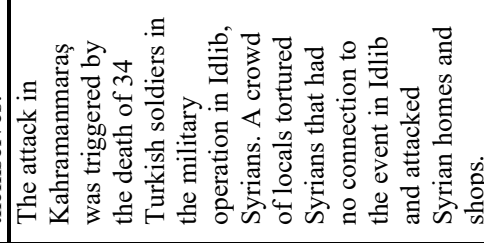 \\
\hline & 施 & & \\
\hline 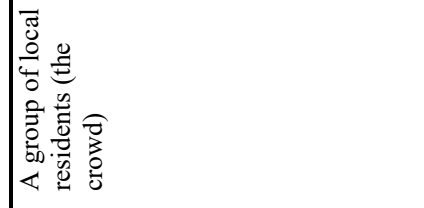 & 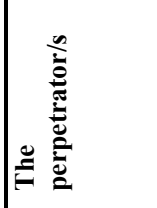 & 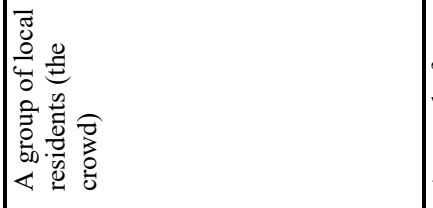 & 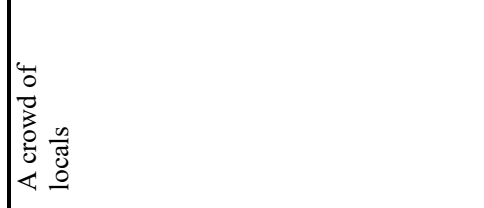 \\
\hline 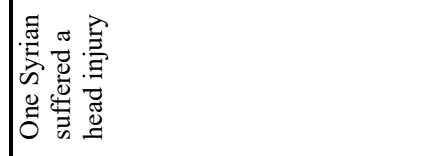 & & 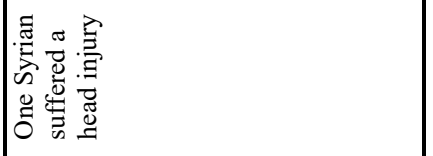 & \\
\hline & & & \\
\hline 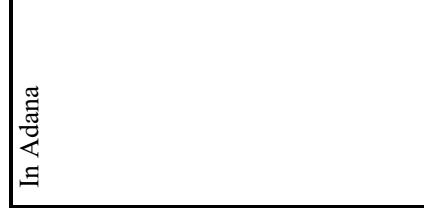 & 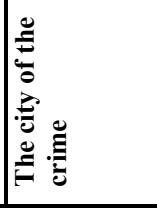 & 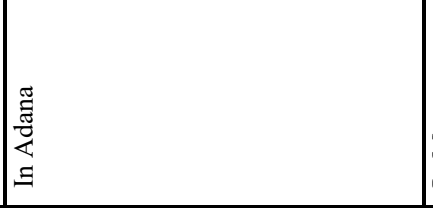 & 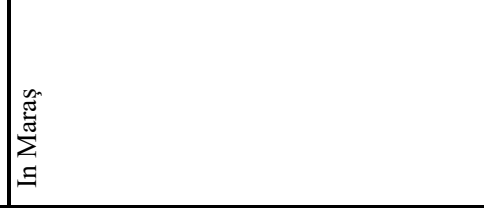 \\
\hline $610 \tau^{\circ} 60^{\circ} \mathrm{II}$ & 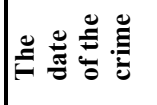 & $6100^{\circ} 60^{\circ} \mathrm{II}$ & 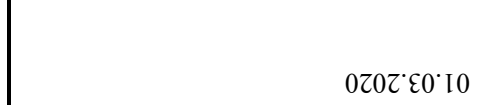 \\
\hline
\end{tabular}




\begin{tabular}{|c|c|c|c|}
\hline 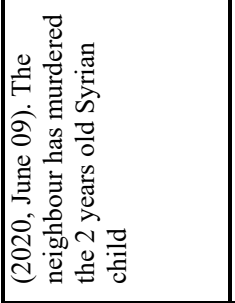 & 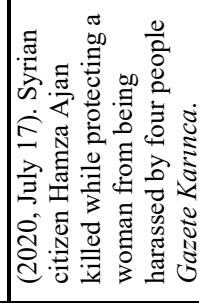 & 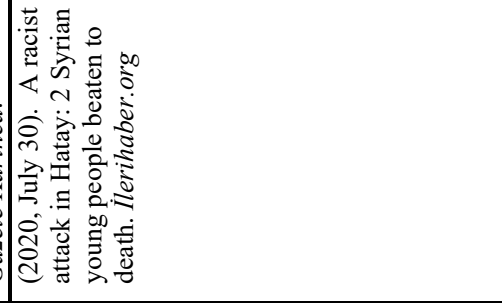 & 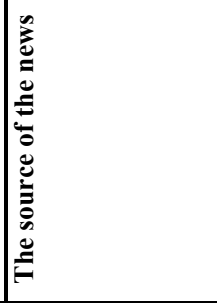 \\
\hline 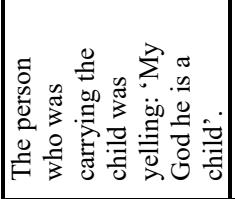 & & & 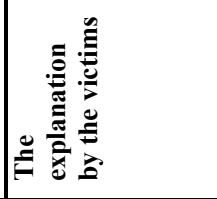 \\
\hline 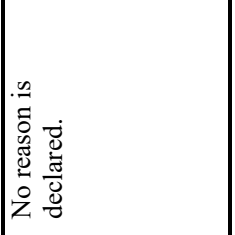 & 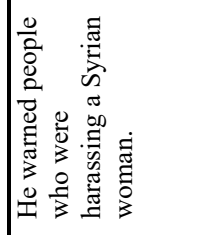 & 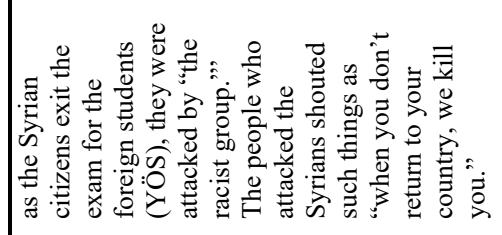 & 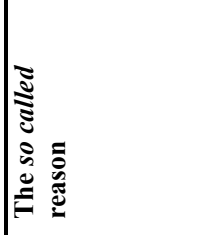 \\
\hline & 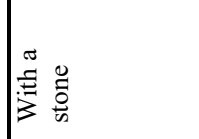 & \begin{tabular}{|l} 
E \\
言 \\
$\frac{5}{5}$ \\
\end{tabular} & 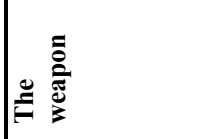 \\
\hline 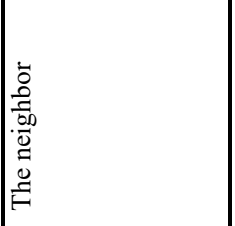 & 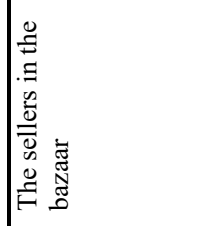 & 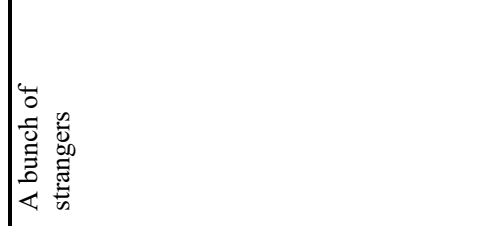 & 产 \\
\hline & & 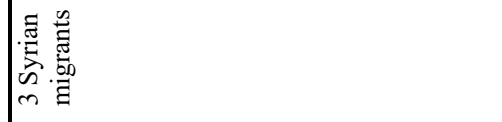 & 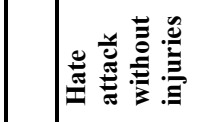 \\
\hline 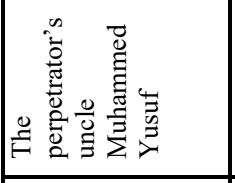 & & 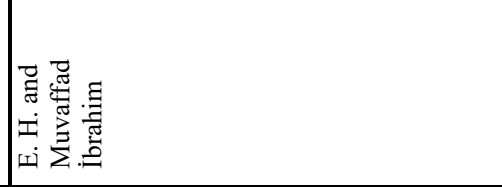 & 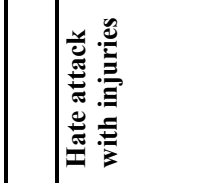 \\
\hline 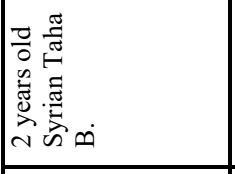 & 旅 & & 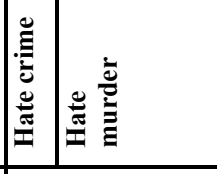 \\
\hline 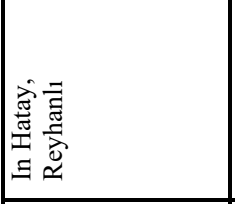 & 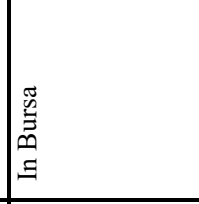 & 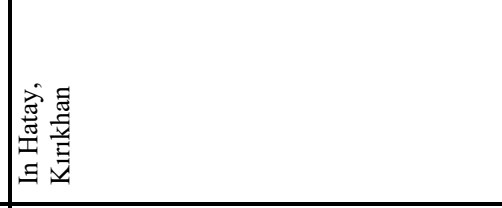 & 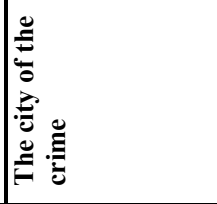 \\
\hline 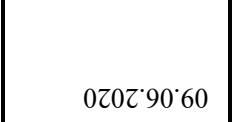 & $0 z 0 \tau^{\circ} \angle 0^{\circ} \angle L$ & ozoz' $\angle 0^{\circ} 0 \varepsilon$ & 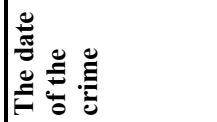 \\
\hline
\end{tabular}




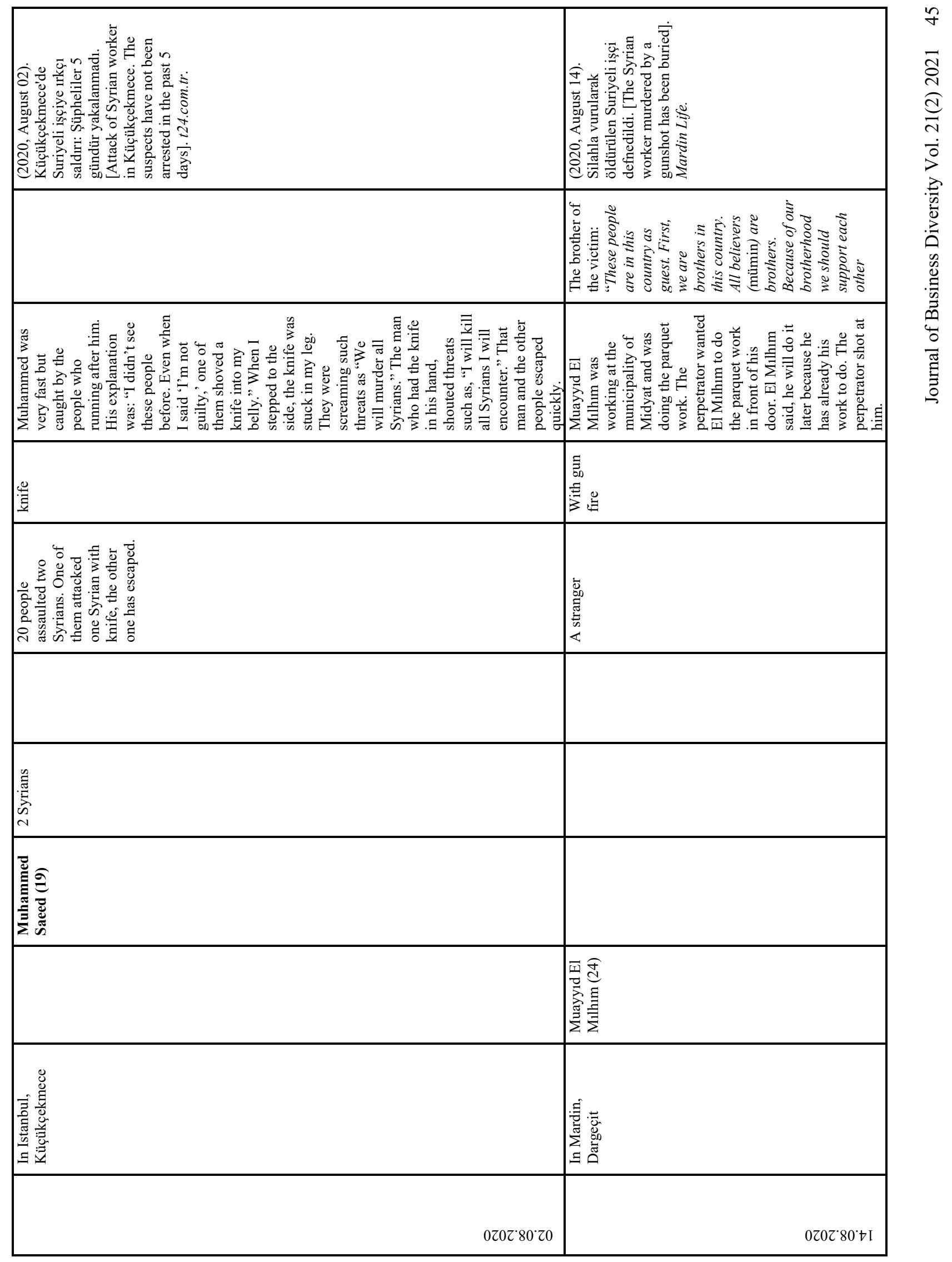




\begin{tabular}{|c|c|c|c|}
\hline 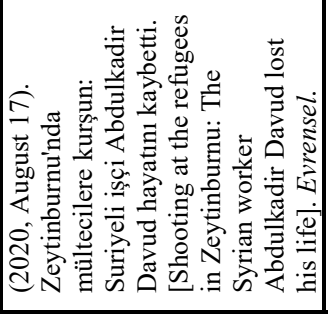 & 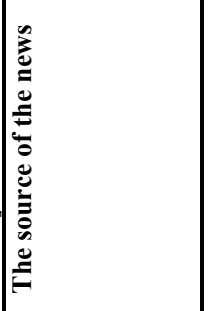 & 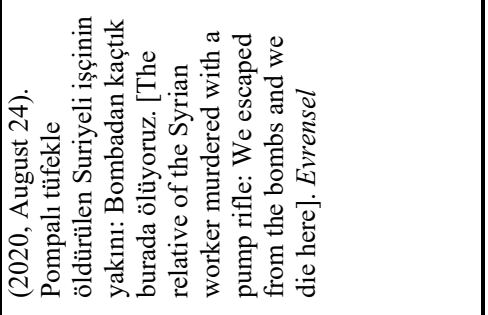 & 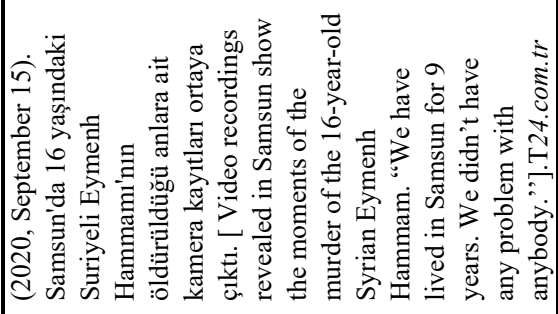 \\
\hline 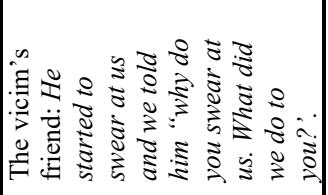 & 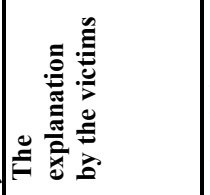 & 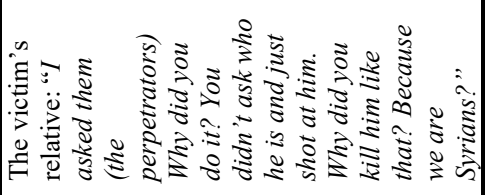 & 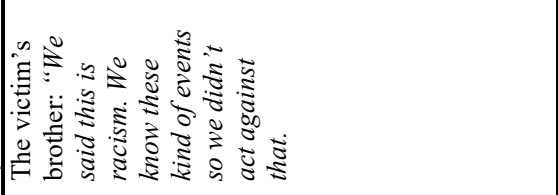 \\
\hline 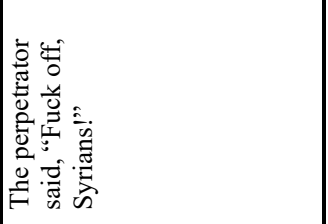 & 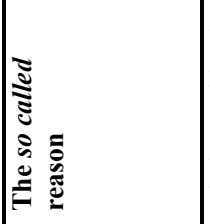 & 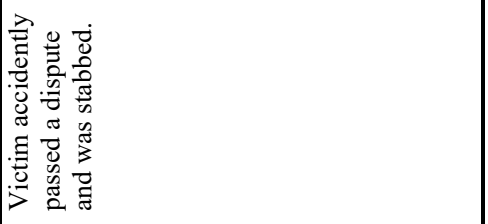 & 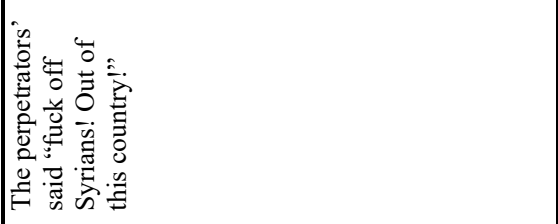 \\
\hline $\begin{array}{l}\stackrel{g}{\mathscr{G}} \\
\Xi \\
\vdots\end{array}$ & 䓂 & 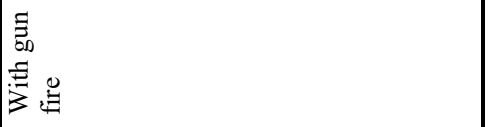 & 造 \\
\hline 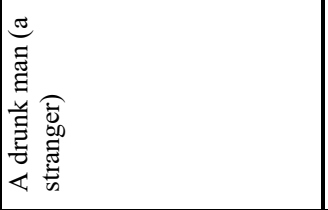 & 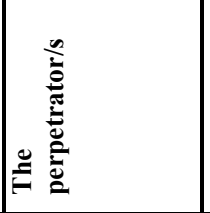 & 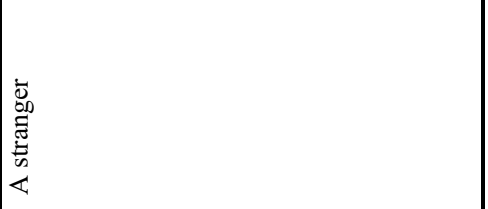 & 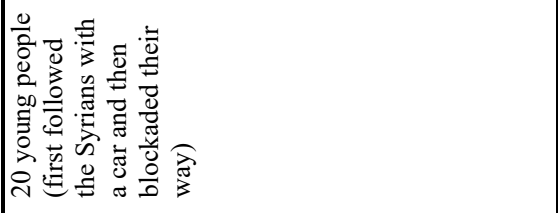 \\
\hline & 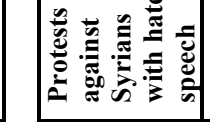 & & \\
\hline 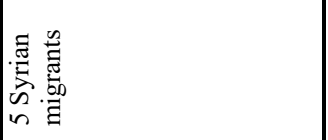 & 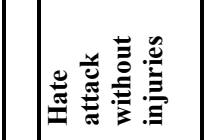 & & 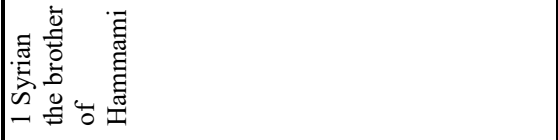 \\
\hline & 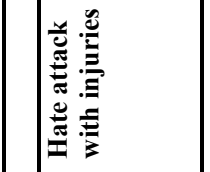 & & \\
\hline 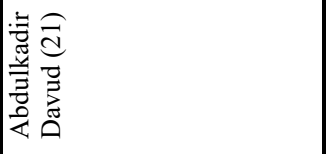 & 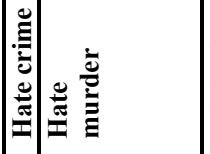 & 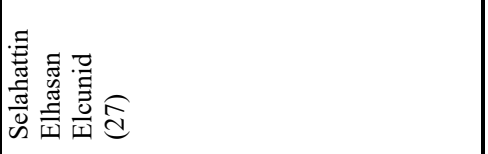 & 氞 \\
\hline 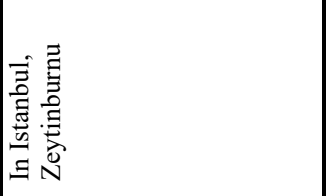 & 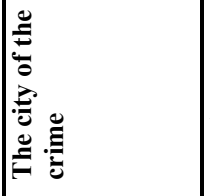 & 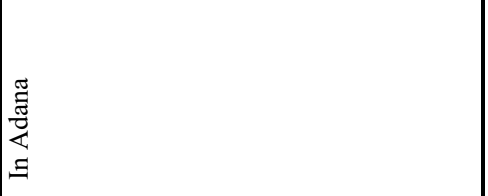 & 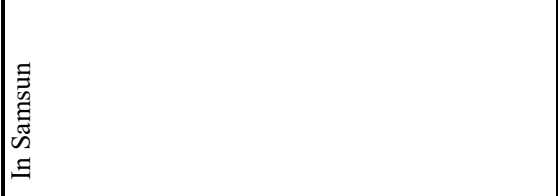 \\
\hline $0 Z 0 Z^{\circ} 80^{\circ} \mathrm{LI}$ & 气 & $0 z 0 \tau^{\circ} 80^{\circ} \pitchfork \tau$ & $0 z 0 z^{\circ} 60^{\circ} \downarrow I$ \\
\hline
\end{tabular}

